\title{
Allergy and Atopic Diseases: An Update on Experimental Evidence
}

\author{
Daniëlle Verschoor Stephan von Gunten \\ Institute of Pharmacology, University of Bern, Bern, Switzerland
}

\begin{abstract}
Keywords
Atopic diseases · Food allergy · Rhinitis - Asthma ·

Dermatitis
\end{abstract}

\begin{abstract}
Over the last decades, an increasing appearance of allergies and atopic disorders, such as asthma, dermatitis, and rhinitis, has been observed. The mechanisms of these disorders remain unclear, and therefore the development of novel therapies is limited. Current treatments are often symptomatic, nonspecific, or may have severe side effects. Further insights into the mechanisms of the underlying disease pathogenesis could reveal novel targets for treatment. In this review, we provide an update on recent basic and translational studies that offer novel insights and opportunities for the treatment of patients with atopic disorders.

๑) 2019 S. Karger AG, Basel
\end{abstract}

\section{Introduction}

Atopy refers to the genetic predisposition of developing allergy-related diseases such as asthma, dermatitis, food allergies, or rhinitis [1]. These diseases are characterized by an exaggerated immune response to environmental allergens and are eventually associated with the production of allergen-specific immunoglobulin E (IgE). Distinct environmental, but also genetic, factors influ-
(C) 2019 S. Karger AG, Basel ence the risk of developing allergen-specific IgE sensitization [2]. Atopic disorders not only affect the patient's physical and psychological state, but may culminate in life-threatening conditions $[3,4]$.

Atopic diseases often develop as an atopic march [5, 6]. The symptoms or diseases follow a certain pattern, starting with the development of atopic dermatitis (AD) and food allergy followed by allergic asthma and rhinitis $[1,6-8]$. The frequency of these disorders has been increasing over the past decades and they therefore have a high societal impact [9-13]. Currently used drugs, such as corticosteroids, have their benefits, but also limitations [14-16], and novel insights into disease mechanisms are required for the identification of novel and improved treatment options. In this article, we highlight recent findings derived from experimental research.

\section{Asthma}

Asthma is a chronic respiratory disease and can be triggered by many different factors, such as allergens, airway infections, exercise, pollutants, and drugs [17, 18]. Typical asthma symptoms are wheezing, coughing, and breathlessness, and asthmatic patients may have a higher risk of airway inflammation and hypersensitivity to non-

Edited by: H.-U. Simon, Bern.

\section{KARGER}

E-Mail karger@karger.com

www.karger.com/iaa
Prof. Stephan von Gunten

Institute of Pharmacology, University of Bern

Inselspital INO-F

$\mathrm{CH}-3010$ Bern (Switzerland)

E-Mail stephan.vongunten@ pki.unibe.ch 




Fig. 1. Infection of BECs by RSV may result in upregulation of the Notch1 ligand JAG1, but downregulation of JAG2, and secretion of TSLP and CSF2, with consecutive Th2 polarization. BEC, bronchial epithelial cell; JAG1, Jagged-1; JAG2, Jagged-2; RSV, respiratory syncytial virus; Th2, T-helper 2.

steroidal anti-inflammatory drugs $[19,20]$. However, different disease phenotypes exist, and associations of allergic or nonallergic forms of asthma have been linked to certain genotypes. Human leukocyte antigen (HLA)$\mathrm{B}^{*} 42$, HLA-C*17, HLA-DPA*03, and HLA-DPB1*105 are associated with nonallergic asthma, while the presence of HLA-DPA $1 * 03$ together with DQA*05 is associ- ated with allergic asthma [20]. For decades, the main treatment strategies focused on bronchodilators and steroids $[17,18,21]$, and a better understanding of the pathogenetic processes may help to identify novel and more personalized therapeutic approaches.

MicroRNAs (miRNAs) are noncoding single-stranded RNAs which can regulate the expression of gene products and thus mediate effects on cell differentiation and activities that influence immune responses [22-24]. When a mouse macrophage-like cell line was stimulated with the T-helper 2 (Th2) cytokines IL-4 and IL-13, an upregulation of mRNA of proinflammatory markers, such as Ccl3, Ccl5, Ccl17, Ccl24, and IL1b, was observed [25]. This effect was enhanced when such pretreated cells were exposed to IL-33, and paralleled by IL-33-dependent upregulation of miR-155-5p, which may eventually involve the downregulation of negative regulators of inflammation [25]. Another group reported that miR-146a mimics attenuated airway inflammation and airway hyperresponsiveness in an ovalbumin (OVA)-induced model of asthma in BALB/c mice [26]. These effects appeared to be dependent on IL-33. Together, these studies suggest that IL-33 could be involved in several miRNAmediated effects. However, the broad analysis of miRNA profiles of immune cells might provide novel insights. For instance, the investigation of a panel of 762 miRNAs revealed elevated levels of numerous miRNAs in mast cells derived from CD133-positive stem cells isolated from allergic asthmatic patients and nonatopic controls upon IgE-mediated sensitization and activation [27]. miR-210 expression was elevated eightfold following IgE-mediated activation, and the miR-132/212 cluster upon activation. However, more mechanistic studies will be required for a better understanding of the expression dynamics and networks that are orchestrated by miRNAs in atopic disorders [23].

Accumulating evidence suggests that the Notch pathway appears to play a role in balancing Th2- or Th1-driven responses $[28,29]$. Recently, it was shown that infection of bronchial epithelial cells by respiratory syncytial virus upregulated the expression of the Notch ligand Jagged-1 (JAG1) and downregulated JAG2 expression, which was associated with increased CSF 2 and TSLP production [29], as illustrated in Figure 1. Coculture of respiratory syncytial virus-infected bronchial epithelial cells with $\mathrm{CD} 4^{+} \mathrm{T}$ cells induced $\mathrm{Th} 2$ polarization, as revealed by the determination of cytokine profiles and expression of the transcription factor GATA3 in T cells. In an animal model, 28 days after respiratory syncytial virus infection, increased IL-4, IL-17, and IFN- $\lambda$ levels were found in lung 
tissue, but not in serum. In this model, increased JAG1 levels and concomitantly decreased JAG2 levels were detected in bronchial epithelial cells after several weeks. In line with this findings, it was shown that gamma-secretase inhibitor (GSI), a blocker of Notch1 signaling pathways, alone or in combination with dexamethasone (DEX), ameliorated airway inflammation and hyperresponsiveness in a model of OVA-induced asthma [28]. This was associated with a shift from a Th2 to a Th1 cytokine profile and enhanced T-bet and reduced GATA3 expression if the Notch pathway was suppressed. Suppression of Notch1 was also found for DEX, in absence of clear evidence for additional synergistic effects of DEX and GSI.

Recently, the effects of a novel antibody, TSP-2, with specificity for toll-like receptor 2 (TLR2) in an OVA-induced allergic model of asthma with $\mathrm{BALB} / \mathrm{c}$ mice were analyzed [30]. Similar to the synthetic TLR2/1 agonist $\mathrm{Pam}_{3} \mathrm{CK}_{4}$, TSP-2 reduced OVA-specific IgE, airway hyperresponsiveness, pulmonary inflammation, as well as leukocyte infiltration and promoted a Th1 cytokine response. Furthermore, the effects of TSP-2 on dendritic cell (DC) maturation were similar to those of $\mathrm{Pam}_{3} \mathrm{CK}_{4}$. Future studies will be required to test the effects of TSP-2 on human cells and the suitability for clinical applications in patients.

In a recent study, it was proposed that extracts from the house dust mite Dermatophagoides farinae ( $D f)$ or Der $f 1$ could directly modify cellular activities of human eosinophils [31]. Df extract or Der $\mathrm{f} 1$ concentration-dependently promoted the adhesion of eosinophils to ICAM-1 and eosinophil superoxide anion generation or secretion of eosinophil-derived neurotoxin in vitro. In blocking assays, anti- $\alpha \mathrm{M}$ - or anti- $\beta 2$-integrin antibodies suppressed these effects. Furthermore, protease-activated receptor 2 was shown to be involved in these processes, given that a blocking antibody partially inhibited $D f$ extract or Der f 1-mediated effects on eosinophils. Notably, eosinophils from allergic patients exhibited higher adhesion to ICAM-1 than those from healthy counterpart upon incubation with $D f$ extract or Der $\mathrm{f} 1$.

Sialic acid-binding immunoglobulin-like lectins ( $\mathrm{Si}$ glecs) represent a family of surface receptors that recognize sialoglycans and exhibit cell type- and differentiation-dependent expression on immune cells [32, 33]. Both inhibitory and proapoptotic effects of Siglecs have been reported, depending on the cell type and the inflammatory environment [34-40]. Siglec- 8 has been shown to have proapoptotic effects on eosinophils [34], while for instance on mast cells this receptor transduces inhibitory,

Update on Experimental Allergy but not proapoptotic, effects [37]. In human airways, sialylated keratan sulfate proteoglycans appear to act as Siglec-8 ligands [41]. Similar to their counterparts in the blood, $48 \mathrm{~h}$ after segmental lung allergen challenge of patients with mild allergic asthma, eosinophils in bronchoalveolar lavage fluid exhibit high unimodal expression of Siglec-8, indicating a potential for therapeutic targeting for eosinophil depletion [42]. Intravenous immunoglobulin preparations contain naturally occurring functional antibodies to Siglec-8 [43], yet monoclonal antibodies may allow for more specifically targeted therapy. A humanized nonfucosylated IgG1 anti-Siglec-8 antibody, AK002, is currently under investigation [44]. In a recent study, AK002 was shown to selectively bind to mast cells, eosinophils, and basophils from human blood or tissue and to exhibit proapoptotic effects on IL-5-activated blood eosinophils and antibody-dependent cellular cytotoxicity activity against eosinophils in the presence of natural killer cells [44]. AK002 reduced the number of eosinophils in dissociated human lung tissue sections when incubated overnight. Furthermore, in a model of passive systemic anaphylaxis in humanized NSG-SGM3BLT mice, which exhibit Siglec-8-expressing human mast cell populations [45], the mouse precursor of AK002 reduced the mast cell-mediated anaphylaxis [44]. Provided the significant species differences, the use of humanized mouse models for investigations on Siglecs has previously been advocated [38].

\section{Food Allergy}

Food allergy occurs when the immune system responds to a normally innoxious food allergen, eventually resulting in gastrointestinal or airway inflammation [8]. When infants are stopped from being breastfed, they can respond to food allergens upon the first intake, given that allergens, such as peanut allergens, can be transferred via breast milk [46]. Another way to become sensitized with allergens could relate to the use of cosmetic products. In animals with a slightly damaged skin, the topical application of lysed wheat proteins [47] or peanut oil [48] resulted in an allergic response after challenge. In the peanut-oil treated mice, an intranasal challenge with peanut extract caused a systemic response with increased numbers of circulating leukocytes and elevated serum levels of IL-13 and IgE [48]. Anaphylactic responses towards food allergens occur more frequently in children compared to adults [49], and the risk was shown to be increased with a previous history of anaphylaxis to foods $[50,51]$, the 
patient's age [50], or high allergen-specific IgE [51]. However, not all food allergies are IgE-mediated, and responses can be delayed [8], which needs also to be considered for the development of diagnostic tools [52]. Patients often show responses to multiple allergens, and it has been observed that patients with walnut or hazelnut allergy often react to other nuts [53]. Furthermore, cashew nut allergy is often associated with cross-reactivity to Anacardiaceae and tree nut species [54], and peanut allergy can be linked to cosensitization for peach [55].

In order to present allergens to allergen-specific $\mathrm{T}$ cells, DCs need to internalize antigens; researchers observed an increased rate of internalization of roasted peanut allergen Ara h 3 compared to raw Ara h 3 in monocyte-derived DCs [56]. This increased internalization seems to be dependent on the mannose receptor, as the internalization was suppressed when this receptor was blocked. Evidence indicates that upon expansion in vitro, peanut allergen Ara h 2-specific T cells isolated from peanut allergy patients exhibit upregulated transcription of multiple genes compared to cells from nonatopic controls [57]. Such gene products included TGF- $\beta$-activated kinase 1 and MAP3K7-binding protein (TAB3), calcium/ calmodulin-dependent protein kinase type IV, and HemK methyltransferase family member 1 . In contrast, in unstimulated peripheral blood mononuclear cells from peanut allergy patients, TAB3 was downregulated compared to their counterparts from atopic non-peanut allergy.

The gut microbiota of atopic patients appear to exhibit specific characteristics [58]. Interestingly, six different bacterial species from the fecal microbiome of children with $\mathrm{AD}$ were found to discriminate between patients with and without food allergy: Bifidobacterium breve, Bifidobacterium pseudocatenulatum, Bifidobacterium adolescentis, Escherichia coli, Faecalibacterium prausnitzii, and Akkermansia muciniphila [58]. Changes in microbiota can be observed in animal models of food allergy, whereby the colon seems more sensitive for microbial changes in response to dietary supplements or allergies compared to other intestinal segments [59]. Dietary intake of fructo-oligosaccharides, prebiotics thought to have a beneficial effect on the composition of the microbiota, showed moderate protection against OVA-induced allergic inflammation of intestines in a mouse model [60]. Reduced levels of Th2 cytokines, such as IL- 4 and IL-13, were shown in the intestine, and reduced numbers of IFN- $\gamma^{+} / \mathrm{IL}^{+}$and $\mathrm{CD} 45 \mathrm{RB}^{\text {high }} / \mathrm{CD} 69^{+} \mathrm{CD} 4^{+} \mathrm{T}$ cells in mesenteric lymph nodes. However, serum levels of mMCP1 and total IgE were not completely restored to normal levels.
Cow's milk allergy is among the most common IgEmediated food allergies, and hypoallergenic infant formulas are available that differ in the degree of hydrolysis of the protein fraction aiming at the destruction of allergenic epitopes. In a recent study, whey-based extensively hydrolyzed infant formula, partially hydrolyzed infant formula, or intact beta-lactoglobulin (BLG) were tested as preventive or desensitizing regimens in a model of allergy-prone, high-IgE responder Brown Norway rats [61]. In the preventive regimen, BLG or partially hydrolyzed infant formula, but not extensively hydrolyzed infant formula with more degraded proteins, induced tolerance as indicated by absence of BLG-specific IgE following intraperitoneal immunization. In the desensitizing regimen, BLG-specific IgE was increased in the groups treated with hydrolyzed infant formulas, but not BLG, suggesting that the intact allergen is required for desensitization. This observation suggests that different infant formulas may be needed for primary prevention or cow's milk allergy desensitization and that the involved mechanisms may differ significantly. However, another study using casein, the most dominant causal allergen in cow's milk allergy, or casein hydrolysate, observed oral tolerance for both preparations, but tolerance induction was higher for the nonhydrolyzed preparation [62]. Oral treatment of BALB/C mice with casein or casein hydrolysate was reported to be associated with lower serum levels of casein-specific IgE and IgG1 and a lower plasma concentration of $\mathrm{mMCP} 1$ as well as a suppressed anaphylaxis response.

\section{Rhinitis}

The characteristics of rhinitis are inflammation and irritation of the nasal mucosal membranes and can be categorized into three groups - nonallergic rhinitis, allergic rhinitis (AR), and chronic rhinosinusitis (CRS) - whereby the latter can be further subdivided into CRS with nasal polyps (CRSwNP) and without nasal polyps (CRSsNP). The major allergens for AR are airborne allergens, and differences in environmental exposure and climate have significant effects on sensitization to perennial and seasonal allergens [63]. AR appears to have a higher prevalence in boys than girls during childhood, while in adults it more frequently affects females than males, with the exception of Asian populations [64]. However, the prevalence of AR was shown to be increased with age [65]. It was proposed that the birth season can influence the development of AR, as increased methylation of the IFNG gene promoter in $\mathrm{CD}^{+} \mathrm{CD}^{-} \mathrm{T}$ cells and lower numbers 
Fig. 2. Potential mechanisms of TGF- $\beta 1$ and mi-R21-induced epithelial-mesenchymal transition in PHNEC involving the PTEN/Akt signaling pathways. PHNEC, primary human nasal epithelial cells.
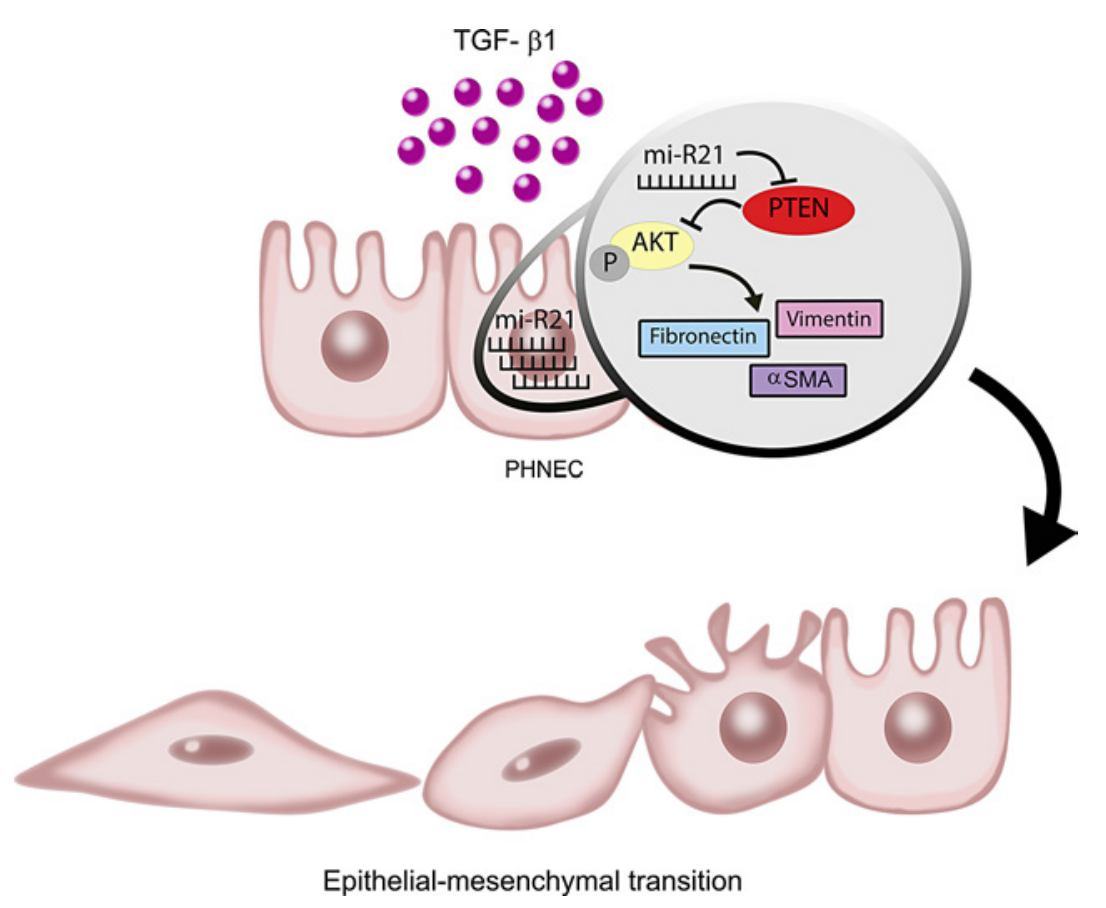

of IFN $-\gamma^{+} \mathrm{CD}^{+} \mathrm{CD} 8^{-} \mathrm{T}$ cells were found in children with AR born in autumn or winter [66]. However, the biological mechanisms behind the seasonal differences in methylation and the development of AR remain unclear. In a population in Northwest China, the number of circulating eosinophils was associated with an increased risk of developing CRSwNP [67].

Recently, it was shown that TGF- $\beta 1$ induces epithelialmesenchymal transition (EMT) of primary human nasal epithelial cells [68]. Evidence for considerable EMT was found in mucosal tissues from CRSwNP patients, based on increased mesenchymal markers, such as $\alpha$-smooth muscle actin, fibronectin, and vimentin, and reduced levels of the epithelial marker E-cadherin. In CRSwNP subjects, but not in CRSsNP subjects or controls, increased levels of TGF- $\beta 1$ RNA and miR-21 were observed. When primary human nasal epithelial cells were treated with TGF- $\beta 1$, mesenchymal markers were progressively induced over 5 days, and EMT was shown to depend on miR-21 and on the PTEN/Akt pathway (Fig. 2). Overexpression of miR-21 may result in downregulation of PTEN and upregulation of Akt phosphorylation.

Recent evidence suggests that silencing costimulatory molecules on DCs might provide a therapeutic strategy for the treatment of allergic disorders. In an in vivo mod- el of AR, it was shown that silencing of both CD40 and CD86 by siRNAs in OVA-pulsed DCs appeared to be more efficient in downregulating allergic symptoms and allergic responses than silencing of either costimulatory receptor alone (Fig. 3), eventually involving upregulation of the Foxp3 gene [69]. The authors discuss a potential translation of these finding into treatment for humans, which might involve the silencing of CD 40 and CD 86 by siRNA and pulsing of monocyte-derived autologous DCs with antigens ex vivo, and transfer of these CD40/86-silenced antigen-pulsed DCs to control allergic diseases in the patient.

The eosinophil chemoattractant and activator 5-oxo6,8,11,14-eicosatetraenoic acid (5-oxo-ETE) was recently studied in the context of nasal polyps [70]. Levels of eosinophil cation protein were increased when isolated blood eosinophils or nasal polyp cultures were treated with the lipid mediator 5-oxo-ETE [70]. The synthesis of 5-oxo-ETE by healthy nasal epithelial cells was induced by $\mathrm{H}_{2} \mathrm{O}_{2}$ treatment. In contrast, oxidative stress stimulation was not required for the generation of 5-oxo-ETE by epithelial cells from nasal polyps ex vivo, suggesting that these cells were previously primed under disease conditions in vivo. Eosinophils from nasal polyps produced higher amounts of eosinophil cation protein upon stimu- 
Fig. 3. Silencing of the costimulatory receptors CD40 and CD86 by siRNA in autologous allergen pulsed DCs as a potential strategy to downregulate allergic immune responses. DC, dendritic cell.

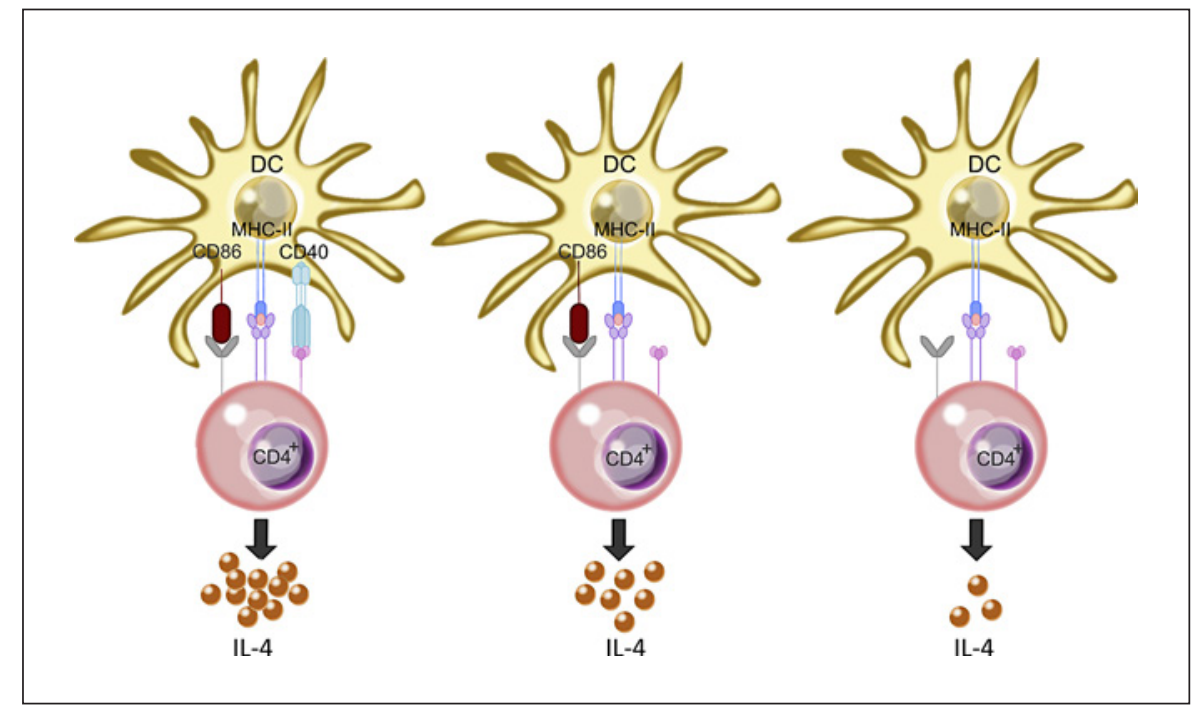

lation with 5-oxo-ETE, an effect that could be reverted upon treatment with pertussis toxin, which was selected as an antagonist for the 5-oxo-ETE receptor (OXER) as a $\mathrm{Ga}_{\mathrm{i}}$-coupled $\mathrm{G}$ protein-coupled receptor. The investigators also found that infiltrates of inflammatory cells in nasal polyps exhibited increased expression of the receptor OXER. These results suggest a role of 5-oxo-ETE in the pathogenesis of nasal polyps.

An important characteristic of rhinitis is the diminution of mucociliary clearance, which correlates with the severity of the rhinitis, the intensity of inflammation, and the infiltration with eosinophils [71]. Researchers observed that mRNA of Foxhead box J1 (FoxJ1) and other cilia structure markers, such as dynein axonemal intermediate chain 1, dynein axonemal light intermediate chain 1 , and dynein axonemal heavy chain 9 , are reduced in AR [72]. The protein FoxJ1 was dyslocalized and more frequently found in the nuclei and axoneme, throughout the entire or part of the axoneme, or completely absent. This observation suggests that FoxJ1 could be relevant for the diminution of mucociliary clearance in AR.

Furthermore, studies showed elevated Notch1 and JAG1 serum levels in AR, correlating with the severity of $A R$ and the level of allergen-specific IgE [73]. Increased levels of Notch1, JAG1, and NICD, the secreted intracellular domain of Notch receptor, were observed in nasal mucosa in an AR mouse model. Levels were restored to normal when mice were treated with the Notch inhibitor GSI. Moreover, the marker for regulatory T cells, Foxp3, was downregulated; this observation might explain the diminished number of regulatory $\mathrm{T}$ cells. Interestingly, blocking the Notch pathway restored the levels of regulatory T cells. Upregulation of IL-6, IL-17, and IL-10 and downregulation of IL- 2 and IFN- $\gamma$ indicated a polarization towards a Th2 imbalance in AR. Once more the levels were reestablished to normal when treated with GSI. This Th1/Th2 imbalance can also be affected by administration of IL-27, which is an initiator of the Th1 response and inhibits inflammatory responses due to the inhibition of Th2 cytokine production and Th2 response [74]. This was illustrated in an OVA-allergic mouse model where cytokine levels of IL-10 and IL-35 were augmented after intranasal IL-27 administration. Additionally, the eosinophil count in the bronchoalveolar lavage fluid was reduced [75]. The reduction of eosinophil counts could be explained by the decreased IL-5 levels. The investigators also observed that IL-27 administration increased the gene expression of Foxp 3 as well as the $\mathrm{CD} 4^{+} \mathrm{CD} 25^{+} \mathrm{Foxp} 3^{+}$ cell count and decreased OVA-specific IgE production. Administration of IL-27 also diminished symptoms such as airways hyperresponsiveness, sneezing, and nose rubbing.

Suppressor of cytokine signaling 3 (SOCS3) was recently shown to be upregulated at the protein level in human AR nasal mucosa, in particular in inflammatory cells [76]. SOCS3 expression levels were shown to be regulated by miR-30a-p5, which was found to be lower in AR. In an animal model of OVA-induced AR, agomiR-30a-5p reduced serum concentrations of OVA-specific IgE and lowered SOCS3 expression levels in nasal mucosal tissue.

In patients with CRSwNP, increased levels of IL21 -producing cells were found in nasal polyp tissue, 
which included in part CXCR5-positive T-follicular helper cells [77]. Tissue stimulation with Staphylococcus aureus enterotoxin B resulted in increased levels of IL-21 mRNA and IL-21-positive T cells in nasal polyp tissue. Given the capacity of CXCR5-positive T-follicular helper cells to promote B cell proliferation and differentiation, bacterial triggers, T-follicular helper cells, and IL-21 may play a crucial role in the pathogenesis of CRSwNP.

\section{Atopic Dermatitis}

$\mathrm{AD}$ is a chronic inflammatory disease characterized by skin lesions and Th2-type-driven inflammation [78]. Despite such polarization, serum levels of Th1-type cytokine tumor necrosis factor alpha (TNF- $\alpha$ ) and TNFR1 ${ }^{+}$T lymphocytes and TNFR $1^{+}$and TNFR2 ${ }^{+} \mathrm{B}$ lymphocytes were found to be increased in AD patients [79]. The serum levels of TNF- $\alpha$, the soluble TNFR1 and TNFR2 receptors, and the frequency of TNFR2 ${ }^{+}$monocytes correlated with disease severity, as assessed using the Scoring Atopic Dermatitis index.

A cornerstone of $\mathrm{AD}$ treatment are topical corticosteroids [80]. Researchers investigated the effects of DEX on mast cells [81]. Epidermal thickening and increased numbers of keratinocyte growth factor-expressing mast cells were observed upon cutaneous DEX injection. Increased production of keratinocyte growth factor was also found for in vitro cultures of the human mast cell line HMC-1 upon DEX stimulation. Supernatants from DEX-treated HMC-1 cells enhanced the proliferation of keratinocytes, an effect that could be reduced in the presence of antikeratinocyte growth factor blocking antibodies. These results suggest that mast cells might influence epidermal growth after corticosteroid appliance.

\section{Outlook}

The prevalence of atopic diseases has increased over the last decades, while their mechanisms are complex and remain to be fully understood. In this update article, we summarized recent findings generated by experimental work from different groups. The variety of new insights will hopefully foster innovation and opportunity recognition or highlight the limitations of currently used models. For instance, models of humanized mice may help to cope with species differences in terms of molecules $[38,44]$ or divergent cellular characteristics, such as those observed for cell death responses of granulocytes [82]. Pluripotent immunomodulatory agents, such as glucocorticoids, vitamin D, or intravenous immunoglobulin, might serve as a further source for opportunity recognition, yet their complex mechanisms of action remain to be deciphered $[83,84]$. Several studies highlighted in this article adopted a reverse translational research approach, from bedside to benchtop. For the future, it is conceivable that reverse translational research in concert with the higher availability of high-throughput methods and biobanks or databanks [85] will direct research and patient care for atopic diseases towards more personalized medicine.

\section{Acknowledgement}

The authors thank Aldona von Gunten, Institute of Pharmacology, University of Bern, Bern, Switzerland, for support with illustrations.

\section{Disclosure Statement}

The authors declare no conflict of interest.

\section{References}

1 Thomsen SF. Epidemiology and natural history of atopic diseases. Eur Clin Respir J. 2015 Mar;2(1):24642.

2 Stemeseder T, Klinglmayr E, Moser S, Lang R, Himly M, Oostingh GJ, et al. Influence of Intrinsic and Lifestyle Factors on the Development of IgE Sensitization. Int Arch Allergy Immunol. 2017;173(2):99-104.

3 Worm M, Edenharter G, Ruëff F, Scherer K, Pföhler C, Mahler V, et al. Symptom profile and risk factors of anaphylaxis in Central Europe. Allergy. 2012 May;67(5):691-8.

4 Grabenhenrich LB, Dölle S, Moneret-Vautrin A, Köhli A, Lange L, Spindler T, et al. Anaphylaxis in children and adolescents:
The European Anaphylaxis Registry. J Allergy Clin Immunol. 2016 Apr;137(4):112837.e1.

5 Han H, Roan F, Ziegler SF. The atopic march: current insights into skin barrier dysfunction and epithelial cell-derived cytokines. Immunol Rev. 2017 Jul;278(1):116-30.

6 Spergel JM. From atopic dermatitis to asthma: the atopic march. Ann Allergy Asthma Immunol. 2010 Aug;105(2):99-106.

7 Yuksel H, Can D, Reisli I, Uzuner N, Orhan F, Cevit $\mathrm{O}$, et al. Characteristics and prognosis of childhood atopic dermatitis: a multicenter study in Turkey. Int Arch Allergy Immunol. 2010;152(4):362-7.
$8 \mathrm{Yu}$ W, Freeland DMH, Nadeau KC. Food allergy: immune mechanisms, diagnosis and immunotherapy. Nat Rev Immunol. 2016 Dec;16(12):751-65.

9 Doğruel D, Bingöl G, Altıntaş DU, Seydaoğlu G, Erkan A, Yilmaz M. The Trend of Change of Allergic Diseases over the Years: Three Repeated Surveys from 1994 to 2014. Int Arch Allergy Immunol. 2017;173(3):178-82.

10 Backman H, Räisänen $\mathrm{P}$, Hedman L, Stridsman C, Andersson M, Lindberg A, et al. Increased prevalence of allergic asthma from 1996 to 2006 and further to 2016 - results from three population surveys. Clin Exp Allergy. 2017 Nov;47(11):1426-35. 
11 Nutten S. Atopic dermatitis: global epidemiology and risk factors. Ann Nutr Metab. 2015; 66 Suppl 1:8-16.

12 Nwaru BI, Hickstein L, Panesar SS, Roberts G, Muraro A, Sheikh A, et al. Prevalence of common food allergies in Europe: a systematic review and meta-analysis. Allergy. 2014 Aug; 69(8):992-1007.

13 Skoner DP. Allergic rhinitis: definition, epidemiology, pathophysiology, detection, and diagnosis. J Allergy Clin Immunol. $2001 \mathrm{Jul}$ 108(1 Suppl):S2-8.

14 Karaulov AV, Vylegzhanina T, Ovchinnikov A, Chernikova M, Nenasheva N. Triamcinolone Acetonide versus Fluticasone Propionate in the Treatment of Perennial Allergic Rhinitis: A Randomized, Parallel-Group Trial. Int Arch Allergy Immunol. 2019;179(2):142-51.

15 Akiyama K, Makihara S, Uraguchi K, Samukawa Y, Oka A, Hoshikawa H. Impact of Preoperative Systemic Corticosteroids on the Histology and Diagnosis of Eosinophilic Chronic Rhinosinusitis. Int Arch Allergy Immunol. 2019;179(2):81-8.

16 Yenigun A, Elbay A, Dogan R, Ozturan O, Ozdemir MH. A Pilot Study Investigating the Impact of Topical Nasal Steroid Spray in $\mathrm{Al}$ lergic Rhinitis Patients with Dry Eye. Int Arch Allergy Immunol. 2018;176(2):157-62.

17 Fahy JV. Type 2 inflammation in asthma present in most, absent in many. Nat Rev Immunol. 2015 Jan;15(1):57-65.

18 Karaulov AV, Garib V, Garib F, Valenta R. Protein Biomarkers in Asthma. Int Arch Allergy Immunol. 2018;175(4):189-208.

19 Guvenir H, Dibek Misirlioglu E, Capanoglu M, Buyuktiryaki B, Onay ZR, Ginis T, et al. The Frequency of Nonsteroidal Anti-Inflammatory Drug Hypersensitivity in Children with Asthma. Int Arch Allergy Immunol. 2018;176(1):26-32.

20 Takejima P, Agondi RC, Rodrigues H, Aun MV, Kalil J, Giavina-Bianchi P. Allergic and Nonallergic Asthma Have Distinct Phenotypic and Genotypic Features. Int Arch Allergy Immunol. 2017;172(3):150-60.

21 Simon D. Recent Advances in Clinical Allergy and Immunology. Int Arch Allergy Immunol. 2018;177(4):324-33.

$22 \mathrm{Hu}$ L, Mao L, Liu S, Zhao J, Chen C, Guo M, et al. Functional Role of MicroRNAs in Thymocyte Development. Int Arch Allergy Immunol. 2019;178(4):315-22.

23 Cortinas-Elizondo F, von Gunten S. MicroRNA-155: microtuning the allergic concert. Allergy. 2015 Sep;70(9):1035-6.

24 Hammond SM. An overview of microRNAs. Adv Drug Deliv Rev. 2015 Jun;87:3-14.

25 Chia N, Kumar RK, Foster PS, Herbert C. Enhanced Pro-Inflammatory Response of Macrophages to Interleukin-33 in an Allergic Environment. Int Arch Allergy Immunol. 2018; 176(1):74-82.

26 Han S, Ma C, Bao L, Lv L, Huang M. miR-146a Mimics Attenuate Allergic Airway Inflammation by Impacted Group 2 Innate Lymphoid Cells in an Ovalbumin-Induced Asthma
Mouse Model. Int Arch Allergy Immunol. 2018;177(4):302-10

27 Just J, Munk Ipsen P, Kruhøffer M, Lykkemark S, Skjold T, Schiøtz PO, et al. Human Mast Cell Sensitization with IgE Increases miRNA-210 Expression. Int Arch Allergy Immunol. 2019;179(2):102-7.

$28 \mathrm{Hu}$ C, Li Z, Feng J, Tang Y, Qin L, Hu X, et al. Glucocorticoids Modulate Th1 and Th2 Responses in Asthmatic Mouse Models by Inhibition of Notch1 Signaling. Int Arch Allergy Immunol. 2018;175(1-2):44-52.

29 Qin L, Qiu KZ, Hu CP, Wu GJ, Wang LL, Tan YR. Bronchial Epithelial Cells Promote the Differentiation of Th2 Lymphocytes in Airway Microenvironment through Jagged/ Notch-1 Signaling after RSV Infection. Int Arch Allergy Immunol. 2019;179(1):43-52.

30 Li K, Huang EP, Su J, Zhu P, Lin J, Luo SQ, et al. Therapeutic Role for TSP-2 Antibody in a Murine Asthma Model. Int Arch Allergy Immunol. 2018;175(3):160-70.

31 Ueda Y, Nakagome K, Kobayashi T, Noguchi T, Soma T, Ohashi-Doi K, et al. Dermatophagoides farinae Upregulates the Effector Functions of Eosinophils through $\alpha \mathrm{M} \beta 2$-Integrin and Protease-Activated Receptor-2. Int Arch Allergy Immunol. 2019;178(4):295-306.

32 von Gunten S, Bochner BS. Basic and clinical immunology of Siglecs. Ann N Y Acad Sci. 2008 Nov; 1143(1):61-82.

33 Adams OJ, Stanczak MA, von Gunten S, Läubli $\mathrm{H}$. Targeting sialic acid-Siglec interactions to reverse immune suppression in cancer. Glycobiology. 2018 Sep;28(9):640-7.

34 Nutku E, Aizawa H, Hudson SA, Bochner BS. Ligation of Siglec-8: a selective mechanism for induction of human eosinophil apoptosis. Blood. 2003 Jun;101(12):5014-20.

35 von Gunten S, Yousefi S, Seitz M, Jakob SM, Schaffner T, Seger R, et al. Siglec-9 transduces apoptotic and nonapoptotic death signals into neutrophils depending on the proinflammatory cytokine environment. Blood. 2005 Aug;106(4):1423-31.

36 von Gunten S, Jakob SM, Geering B, Takala J, Simon HU. Different patterns of Siglec-9-mediated neutrophil death responses in septic shock. Shock. 2009 Oct;32(4):386-92.

37 Yokoi H, Choi OH, Hubbard W, Lee HS, Canning BJ, Lee HH, et al. Inhibition of FcepsilonRI-dependent mediator release and calcium flux from human mast cells by sialic acidbinding immunoglobulin-like lectin 8 engagement. J Allergy Clin Immunol. 2008 Feb; 121(2):499-505.e1.

38 Jandus C, Boligan KF, Chijioke O, Liu $\mathrm{H}$, Dahlhaus M, Démoulins $\mathrm{T}$, et al. Interactions between Siglec-7/9 receptors and ligands influence NK cell-dependent tumor immunosurveillance. J Clin Invest. 2014 Apr;124(4): 1810-20.

39 Stanczak MA, Siddiqui SS, Trefny MP, Thommen DS, Boligan KF, von Gunten S, et al. Selfassociated molecular patterns mediate cancer immune evasion by engaging Siglecs on T cells. J Clin Invest. 2018 Nov; 128(11):4912-23.
40 Haas Q, Boligan KF, Jandus C, Schneider C, Simillion C, Stanczak MA, et al. Siglec-9 regulates an effector memory CD8+ T-cell subset that congregates in the melanoma tumor microenvironment. Cancer Immunol Res. 2019 May;7(5):707-18.

41 Gonzalez-Gil A, Porell RN, Fernandes SM, Wei Y, Yu H, Carroll DJ, et al. Sialylated keratan sulfate proteoglycans are Siglec-8 ligands in human airways. Glycobiology. 2018 Oct; 28(10):786-801.

42 Johansson MW, Kelly EA, Nguyen CL, Jarjour NN, Bochner BS. Characterization of Siglec-8 Expression on Lavage Cells after Segmental Lung Allergen Challenge. Int Arch Allergy Immunol. 2018;177(1):16-28.

43 von Gunten S, Vogel M, Schaub A, Stadler BM, Miescher S, Crocker PR, et al. Intravenous immunoglobulin preparations contain anti-Siglec-8 autoantibodies. J Allergy Clin Immunol. 2007 Apr;119(4):1005-11.

44 Youngblood BA, Brock EC, Leung J, Falahati R, Bryce PJ, Bright J, et al. AK002, a Humanized Sialic Acid-Binding Immunoglobulin-Like Lectin-8 Antibody that Induces Antibody-Dependent Cell-Mediated Cytotoxicity against Human Eosinophils and Inhibits Mast Cell-Mediated Anaphylaxis in Mice. Int Arch Allergy Immunol. 2019; 180(2):91-102.

45 Bryce PJ, Falahati R, Kenney LL, Leung J, Bebbington $\mathrm{C}$, Tomasevic $\mathrm{N}$, et al. Humanized mouse model of mast cell-mediated passive cutaneous anaphylaxis and passive systemic anaphylaxis. J Allergy Clin Immunol. 2016 Sep;138(3):769-79.

46 Schocker F, Scharf A, Kull S, Jappe U. Detection of the Peanut Allergens Ara h 2 and Ara h 6 in Human Breast Milk: Development of 2 Sensitive and Specific Sandwich ELISA Assays. Int Arch Allergy Immunol. 2017;174(1): $17-25$.

47 Ballegaard AR, Madsen CB, Bøgh KL. An Animal Model for Wheat Allergy Skin Sensitisation: A Comparative Study in Naive versus Tolerant Brown Norway Rats. Int Arch Allergy Immunol. 2019;178(2):106-18.

48 Benor S, Shani N, Etkin S, Bondar E, Kivity S, Langier S. Epicutaneous Exposure to Peanut Oil Induces Systemic and Pulmonary Allergic Reaction in Mice. Int Arch Allergy Immunol. 2019;179(3):187-91.

49 Goh SH, Soh JY, Loh W, Lee KP, Tan SC, Heng WJ, et al. Cause and Clinical Presentation of Anaphylaxis in Singapore: From Infancy to Old Age. Int Arch Allergy Immunol. 2018;175(1-2):91-8.

50 Yanagida N, Sato S, Asaumi T, Ogura K, Ebisawa M. Risk Factors for Severe Reactions during Double-Blind Placebo-Controlled Food Challenges. Int Arch Allergy Immunol. 2017;172(3):173-82.

51 Inoue $\mathrm{T}$, Ogura K, Takahashi K, Nishino M, Asaumi T, Yanagida N, et al. Risk Factors and Clinical Features in Cashew Nut Oral Food Challenges. Int Arch Allergy Immunol. 2018; 175(1-2):99-106. 
52 Vandekerckhove M, Van Droogenbroeck B, De Loose M, Coudijzer K, Van Winckel M, Gevaert P, et al. A Novel Double-Blind, Placebo-Controlled Food Challenge Matrix for Milk and Raw Egg. Int Arch Allergy Immunol. 2019;179(1):1-9.

53 Villalta D, Scala E, Mistrello G, Amato S, Asero R. Evidence of Cross-Reactivity between Different Seed Storage Proteins from Hazelnut (Corylus avellana) and Walnut (Juglans regia) Using Recombinant Allergen Proteins. Int Arch Allergy Immunol. 2019;178(1):8992.

54 Bastiaan-Net S, Reitsma M, Cordewener JH, van der Valk JP, America TA, Dubois AE, et al. IgE Cross-Reactivity of Cashew Nut Allergens. Int Arch Allergy Immunol. 2019;178(1): 19-32.

55 Zambrano Ibarra G, Fuentes Aparicio V, Infante Herrero S, Blanca M, Zapatero Remon L. Peanut Allergy in Spanish Children: Comparative Profile of Peanut Allergy versus Tolerance. Int Arch Allergy Immunol. 2019; 178(4):370-6.

56 Cabanillas B, Maleki SJ, Cheng H, Novak N. Differences in the Uptake of Ara 3 from Raw and Roasted Peanut by Monocyte-Derived Dendritic Cells. Int Arch Allergy Immunol. 2018;177(1):35-9.

57 Saidova A, Bublin M, Schmidthaler K, Fajgelj V, Klinglmueller F, Spittler A, et al. Evidence for a Role of TGF- $\beta$-Activated Kinase 1 and MAP3K7 Binding Protein 3 in Peanut-Specific T-Cell Responses. Int Arch Allergy Immunol. 2019;179(1):10-6.

58 Fieten KB, Totté JE, Levin E, Reyman M, Meijer Y, Knulst A, et al. Fecal Microbiome and Food Allergy in Pediatric Atopic Dermatitis: A Cross-Sectional Pilot Study. Int Arch Allergy Immunol. 2018;175(1-2):77-84.

59 Andreassen M, Rudi K, Angell IL, Dirven H, Nygaard UC. Allergen Immunization Induces Major Changes in Microbiota Composition and Short-Chain Fatty Acid Production in Different Gut Segments in a Mouse Model of Lupine Food Allergy. Int Arch Allergy Immunol. 2018;177(4):311-23.

60 Tsuda M, Arakawa H, Ishii N, Ubukata C, Michimori M, Noda M, et al. Dietary FructoOligosaccharides Attenuate Early Activation of CD4+ T Cells Which Produce both Th1 and Th2 Cytokines in the Intestinal Lymphoid Tissues of a Murine Food Allergy Model. Int Arch Allergy Immunol. 2017;174(3-4): $121-32$.

61 Jensen LH, Larsen JM, Madsen CB, Laursen RR, Jacobsen LN, Bøgh KL. Preclinical Brown Norway Rat Models for the Assessment of Infant Formulas in the Prevention and Treatment of Cow's Milk Allergy. Int Arch Allergy Immunol. 2019;178(4):307-14.
62 Iwamoto H, Matsubara T, Okamoto T, Matsumoto T, Yoshikawa M, Takeda Y. Ingestion of Casein Hydrolysate Induces Oral Tolerance and Suppresses Subsequent Epicutaneous Sensitization and Development of Anaphylaxis Reaction to Casein in Mice. Int Arch Allergy Immunol. 2019;179(3):221-30.

63 Charpin D, Ramadour M, Lavaud F, Raherison C, Caillaud D, de Blay F, et al. Climate and Allergic Sensitization to Airborne Allergens in the General Population: Data from the French Six Cities Study. Int Arch Allergy Immunol. 2017;172(4):236-41.

64 Pinart M, Keller T, Reich A, Fröhlich M, Cabieses B, Hohmann C, et al. Sex-Related Allergic Rhinitis Prevalence Switch from Childhood to Adulthood: A Systematic Review and Meta-Analysis. Int Arch Allergy Immunol. 2017;172(4):224-35.

65 Ha EK, Na MS, Lee S, Baek H, Lee SJ, Sheen $\mathrm{YH}$, et al. Prevalence and Clinical Characteristics of Local Allergic Rhinitis in Children Sensitized to House Dust Mites. Int Arch Allergy Immunol. 2017;174(3-4):183-9.

66 Li Y, Rui X, Ma B, Jiang F, Chen J. Early-Life Environmental Factors, IFN- $\gamma$ Methylation Patterns, and Childhood Allergic Rhinitis. Int Arch Allergy Immunol. 2019;178(4):323-32.

67 Chen F, Wen L, Qiao L, Shi Z, Xue T, Chen X, et al. Impact of Allergy and Eosinophils on the Morbidity of Chronic Rhinosinusitis with Nasal Polyps in Northwest China. Int Arch Allergy Immunol. 2019;179(3):209-14.

68 Li X, Li C, Zhu G, Yuan W, Xiao ZA. TGF- $\beta 1$ Induces Epithelial-Mesenchymal Transition of Chronic Sinusitis with Nasal Polyps through MicroRNA-21. Int Arch Allergy Immunol. 2019;179(4):304-19.

69 Suzuki M, Yokota M, Matsumoto T, Ozaki S. Synergic Effects of CD40 and CD86 Silencing in Dendritic Cells on the Control of Allergic Diseases. Int Arch Allergy Immunol. 2018; 177(2):87-96

70 Lin L, Chen Z, Tang X, Dai F, Wei J, Sun G. 5-Oxo-ETE from Nasal Epithelial Cells Upregulates Eosinophil Cation Protein by Eosinophils in Nasal Polyps in vitro. Int Arch Allergy Immunol. 2018;177(2):107-15.

71 Mikolajczyk M, Janukowicz K, Majewska E, Baj Z. Impact of Allergic Rhinitis on Nasal Mucociliary Clearance Time in Children. Int Arch Allergy Immunol. 2019;179(4):297303.

72 Peng Y, Chen Z, Guan WJ, Zhu Z, Tan KS, Hong $\mathrm{H}$, et al. Downregulation and Aberrant Localization of Forkhead Box J1 in Allergic Nasal Mucosa. Int Arch Allergy Immunol. 2018;176(2):115-23.
73 Jiao WE, Wei JF, Kong YG, Xu Y, Tao ZZ, Chen SM. Notch Signaling Promotes Development of Allergic Rhinitis by Suppressing Foxp3 Expression and Treg Cell Differentiation. Int Arch Allergy Immunol. 2019;178(1): 33-44.

74 Meka RR, Venkatesha SH, Dudics S, Acharya B, Moudgil KD. IL-27-induced modulation of autoimmunity and its therapeutic potential. Autoimmun Rev. 2015 Dec;14(12):1131-41.

75 Suzuki M, Yokota M, Ozaki S, Matsumoto T. Intranasal Administration of IL-27 Ameliorates Nasal Allergic Responses and Symptoms. Int Arch Allergy Immunol. 2019; 178(2):101-5.

76 Zhao CY, Wang W, Yao HC, Wang X. SOCS3 Is Upregulated and Targeted by miR30a-5p in Allergic Rhinitis. Int Arch Allergy Immunol. 2018;175(4):209-19.

77 Calus L, Derycke L, Dullaers M, Van Zele T, De Ruyck N, Pérez-Novo C, et al. IL-21 Is Increased in Nasal Polyposis and after Stimulation with Staphylococcus aureus Enterotoxin B. Int Arch Allergy Immunol. 2017;174(3-4): 161-9.

78 Moreno AS, McPhee R, Arruda LK, Howell MD. Targeting the T Helper 2 Inflammatory Axis in Atopic Dermatitis. Int Arch Allergy Immunol. 2016;171(2):71-80.

79 Lopatnikova JA, Alshevskaya AA, Krugleeva OL, Nepomnyschih VM, Gladkikh VS, Lukinov VL, et al. Expression of TNFa Receptors on Immunocompetent Cells Is Increased in Atopic Dermatitis. Int Arch Allergy Immunol. 2017;174(3-4):151-60.

80 Simon D, Wollenberg A, Renz H, Simon HU. Atopic Dermatitis: Collegium Internationale Allergologicum (CIA) Update 2019. Int Arch Allergy Immunol. 2019;178(3):207-18.

81 Cho KA, Kim HJ, Kim YH, Park M, Woo SY. Dexamethasone Promotes Keratinocyte Proliferation by Triggering Keratinocyte Growth Factor in Mast Cells. Int Arch Allergy Immunol. 2019;179(1):53-61.

82 Schneider C, Wicki S, Graeter S, Timcheva TM, Keller CW, Quast I, et al. IVIG regulates the survival of human but not mouse neutrophils. Sci Rep. 2017 May;7(1):1296.

83 von Gunten S, Cortinas-Elizondo F, Kollarik M, Beisswenger C, Lepper PM. Mechanisms and potential therapeutic targets in allergic inflammation: recent insights. Allergy. 2013 Dec;68(12):1487-98.

84 von Gunten S, Shoenfeld Y, Blank M, Branch DR, Vassilev T, Käsermann F, et al. IVIG pluripotency and the concept of $\mathrm{Fc}$-sialylation: challenges to the scientist. Nat Rev Immunol. 2014 May; 14(5):349.

85 Jandus P, Frias Boligan K, Smith DF, de Graauw E, Grimbacher B, Jandus C, et al. The architecture of the IgG anti-carbohydrate repertoire in primary antibody deficiencies (PADs). Blood. 2019 Sep:blood.2019001705. 